\title{
FLOOD CONTROL VIA THE POLICE POWER
}

\section{ALTISON DUNHaM $\dagger$}

\begin{abstract}
Increasing attention is currently being given to consideration of human adjustment to floods. In recent years there have been suggestions that flood-prone areas should be regulated through the exercise of the police power. In this Article, Professor Dunham, an authority in the field of property, examines the history of the movement toward flood-plain zoning and sets forth a conceptual framework by which the consequences of such regulation may be judged. He then analyzes the reasons which underlie the movement and the constitutional basis of its reliance on the police power.
\end{abstract}

Despite extensive study and agitation concerning water resources, public expenditure on water problems, and federal-state relations involving water, ${ }^{1}$ very little change in policy has occurred in the past ten years. Generally speaking, "States-righters" do not let their theology interfere with their business-the business of securing federal expenditures in their states. In December 1958, a conference of state officials, The Fourteenth Biennial Meeting of the General Assembly of the States, proposed that state legislatures begin controlling land use in flood plains with the objective of controlling losses from floods. ${ }^{2}$ In contrast with the usual policy of securing federal funds to construct large preventive works to control flood losses, this proposal involves use of the police power of the states.

$\dagger$ Professor of Law, University of Chicago Law School. A.B., 1936, Yankton College; LL.B., 1939, Columbia University.

1. For a rather complete survey of these problems and an excellent bibliographical source see River Basin Development and Water Resources, 22 LAW \& CoNTEMP. PRoB. 155-537 (1957). See also Eckstein, Water-Resource Deveiopment (1958) (hereinafter cited as Eckstein); Leopold \& Maddock, The Flood Control ConTroversy (1954) (hereinafter cited as Leopold \& MADDOCK) ; Presidential Advisory Comam., Report on Water Resources Policy (1955) ; President's Water Resources Policy Comm'N, Water Resources LaW (1950); Commission on Organization of tHe Executrve Branch of the Government, Task Force Report on Water RESOURCES AND Power (1955) (hereinafter cited as TASK FORCE REPORT); Renshaw, Toward Responsible Government (1957) (hereinafter cited as Renshaw).

2. The resolution adopted by the General Assembly of the States, 14th Biennial Meeting, Flood Plain Regulation and Flood Insurance (Mimeo, Council of State Governments, Dec. 5, 1958), reads in part: "Despite extensive flood control measures, annual flood losses increase. In large part this is due to the growing use of flood plains for residential, commercial, industrial and other purposes. In order to consider the feasibility of various methods of regulating the use of flood plains and flood insurance, a Conference on Flood Plain Regulation and Insurance was sponsored jointly by the Council of State Governments, The American Society of Planning Officials, The American Institute of Planners, The American Society of Civil Engineers and the Department of Geography at the University of Chicago, in Chicago, Illinois, on December 1-2, 1958. State and federal officials attending this conference adopted a statement of conclusions regarding desirable state and federal 
It is proposed that land uses in flood-prone areas be regulated by limiting the types of activities which may be carried on there to less damageable types such as billboards and open-air facilities, by limiting the quantity of permitted activities and by controlling the construction of structures permitted. This regulation will, it is said, reduce the drain on local treasuries during a flood disaster period, reduce demands for federally-built engineering works and, thereby, reduce federal expenditures.

It is the purpose of this paper to examine briefly the history of the movement toward regulation of land use in the flood plain; to suggest a conceptual framework by which the consequences of such regulation may be judged; to analyze the reasons advanced for this restriction on individual decisions concerning use of private land; and, finally, to consider the constitutional basis of this proposed use of the states' police powers.

\section{History of Government Control of Fiood Losses}

Prior to the Flood Control Act of $1936^{3}$ there were only rare references in the literature to "flood-plain zoning," 4 and there were even fewer laws in operation which could be called flood-plain zoning regulation. The literature at this time was primarily a literature of weather, hydrology and engineering, a literature about preventing floods rather than flood losses.

Discussion of land use regulation of flood plains may be said to begin with a deceptively simple and appealing question in the Engineering Nezes-Record of March 1937: "Is it sound economics to let such property be damaged year after year, to rescue and take care of the occupants, to spend millions for their 'local protection', when a slight shift of location would assure safety?" : And following Professor

action in this area. The Fourteenth Biennial General Assembly of the States, recognizing the need for action to cope with this problem, commends to the attention of the states and the federal government the conclusions reached by the conference and urges their implementation by necessary administrative and legislative action." Among the conclusions of this conference were: " 2 . All states should study the need for instituting or extending measures to control encroachment which would impede stream flow. . . 3. Each state should promptly review its existing legislation and administration to determine what steps are needed to authorize the use of zoning, sub-division regulation, building codes and other means of land use regulation to prevent flood losses. . . . 7. All future expenditures of federal funds for protective works yielding primarily localized benefits should be contingent upon regulatory action by state and local governments to control further encroachment upon flood ways. . ." Ibid.

3. 49 Stat. 1570 (1936), as amended, 33 U.S.C. \$\$701-09 (1952), as amended, 33 U.S.C. $\$ \$ 701-1-09$ (Supp. V, 1958).

62 (1928).

4. See, e.g., Shurleff, Flood Destruction and Town Planning, 4 City Planning

5. Engineering News-Record, March 11, 1937, p. 385. 
Gilbert White's Human Adjustment to Floods, ${ }^{\circ}$ in 1942, the flood control literature has undergone an almost complete shift in emphasis from consideration of measures to prevent floods to consideration of human adjustment to floods. Almost all discussion now begins with the premise that flood losses are caused by man, not nature. ${ }^{7}$ If man did not live and work on the flood plain, there would be no flood losses and no need for construction of flood prevention works.

With this shift in emphasis from engineering to man, some startling facts were discovered: "Despite extensive flood control measures, annual flood losses increase." 8 It has been estimated that since 1928 the United States has spent more than four billion dollars on flood control projects and that since 1936 the Red Cross and the federal government have spent several hundred million dollars for flood relief. ${ }^{9}$ Yet the flood losses for 1928-1951 (a period of large federal construction) were 1.38 times that for $1903-1927,,^{10}$ even after adjustment for price levels. The demonstrated ineffectiveness of engineering works and the new emphasis on human adjustment to floods have led many to conclude that an approach preferable to that of large public expenditures is the use of the police power to force human adjustment to floods so that flood losses will not continue to increase. ${ }^{11}$

6. University of Chicago Dep't of Geography Research Paper No. 29, 1942 (1945) (hereinafter cited as WhITE, HUMAN ADJUSTMENT).

7. In the early 1930's it was suggested that soil and forest conservation was the solution to down stream floods. However meritorious this conservation may be, its contribution to flood control is now believed to be negligible. See White, $A$ Perspective of River Basin Development, 22 LAW \& Contemp. Prob. 157, 175-78 (1957) and references cited therein. See also Hoyt \& LANGBern, Floods 180-86 (1955) (hereinafter cited as HoyT \& LANGBEIN) where it is estimated that the "off-site" benefits to flood control are less than $3 \%$ of the total benefits of the activity; LEOPOLD \& MADDOCK 56-82.

8. White, Changes in Urban Occupance of Flood Plains in the UntTed States 9 (University of Chicago Dep't of Geography Research Paper No. 57, 1958) (hereinafter cited as White, URban Occupance). See Hoyt \& LaNGBein 7; Renshaw 42-53.

9. White, URBAN Occupance 20-22.

10. Hoyt \& LANGBein 88.

11. The literature is now quite extensive: Hoyt \& LANGBETn; LEOPOLD \& MADDOCK; StIER, Flood Problems and Them Solution Through Urban Planntang Programs (Tennessee State Planning Comm'n Pub. No. 262, 1955) (hereinafter cited as Siler, Flood Problems); White, Human Adjustarent; American Soc'y of Planning Offictals, Floon Plain Regulation (Planning Advisory Service Report No. 53, 1953); Moore, Planning for Flood Damage Prevention (Engineering Experiment Station, Ga. Institute of Technology Special Rep. No. 35, undated); Albers, New Uses for County Zoning: The Jefferson Connty, Wisconsin Ordinance, 14 J. LAND \& P.U. Econ. 460 (1938) ; Adams, Economic Aspects of Flood Plain Zoning, Proceeding of Am. Soc'y of Civil Engineers (Hydraulics Division Journal), Feb. 1956, paper 882; Behrens, Zoning Against Floods in Milwaukee County, The American City, Sept. 1952, p. 112; Fed. Reserve Bank of Boston, Flood Area Planning and Redevelopment, New England Bus. Rev., Sept. 1958; Fed. Reserve Bank of Boston, Planning for Floods in Nerw England, New England Bus. Rev., Feb. 1956; Kollmorgen, Settlement Control Beats Flood Prevention, 29 EcoN. GEOGRAPHy 208 (1953); Eisenmenger, State and Local Responsibility in Flood Plain Zoning (Address before the New England Council, mimeo, 1956). 
Another approach leading to the same end has been searching economic analysis of the "benefit-cost formulae" used by various public agencies to justify to Congress the construction of engineering works such as reservoirs and levees. The Flood Control Act of 1936 requires the Corps of Engineers to present to Congress, concerning each proposed flood control project, a report which includes comparison of the cost of the project with its benefits. In its introductory clause, the act finds, "that the Federal Government should improve or participate in the improvement of navigable waters or their tributaries . . . for flood-control purposes if the benefits to whomsoever they may accrue are in excess of the estimated costs. . . ." 12 In the early years of the program, when the "better" projects were undertaken, defects in the economics of the benefit-cost calculations mattered little, for the benefits probably exceeded the costs under any system of analysis. But, as the Corps of Engineers began to be pressed by Congress and others toward undertaking more marginal projects, ${ }^{13}$ the accuracy of the calculations came into question. ${ }^{14}$ Economists began to note that a relevant consideration for an informed judgment based on cost-benefit was the cost of alternative methods of reducing flood loss. Among the alternatives noted was that of controlling the occupancy of a flood plain. ${ }^{15}$

The Flood Task Force of the Second Hoover Commission reasoned that pressure for more and costlier federally-built engineering works comes from the economic forces using a flood plain. If these forces were reduced in size the federal expenditures would tend to decrease. The forces could be reduced by flood-plain zoning. ${ }^{16}$

The Flood Insurance Act of $1956,{ }^{17}$ passed after the disastrous New England floods of 1954 and 1955 in effect required states to adopt

12. 49 Stat. 1570 (1936), 33 U.S.C. §701a (1952). (Emphasis added.)

13. Renshaw 51, reports that, based on the Corps of Engineers' own estimates, the estimated gross rate of return on projects completed is $11.1 \%$; for projects under construction but not in operation, $5.6 \%$; and for works authorized but not started, $3.8 \%$.

14. See, e.g., Ecrstern 47-109; Subcommitree To Study Civir Works, House Comm. on Pudic Works, 82p Cong., 2d Sess., Altocation of Costs of Federal Water Resource Development Projects (Comm. Print 23, 1952); 2 Task Force Report 802-09; 3 TASK ForCe REPORT 1275; Renshaze 48-53.

15. White, Human Adjustarent 128-202 lists the following adjustments to floods as possibilities: (1) land elevation, (2) flood abatement, (3) flood protection (levees, channel improvements, diversions, reservoirs), (4) emergency measures (removal, rehabilitation, flood fighting), (5) structural adjustments (buildings, utilities, bridges), (6) land use changes (voluntary, voluntary but subsidized, involuntary but paid for by condemnation, and zoning), (7) public relief, and (8) insurance.

16. 2 TASK FORCE REPORT 730.

17. 70 Stat. 1078 (1956), 42 U.S.C. $\$ \$ 2401-2421$ (Supp. V, 1958). See Housing \& Home Finance Agency, Final Report on the Federal Flood Indemnity Administration, H.R. Doc. No. 426, 85th Cong., 2d Sess. (1958). 
some kind of zoning. Apparently as a means of standardizing risks, this subsidized insurance scheme provided that the insurance could not be made available in a community until the insurance administrator found that the local community had adopted "such flood zoning protection . . . as may be deemed necessary to reduce . . . damages from floods. . . ."18 The Conference on Flood Plain Regulation, referred to earlier, thought that flood plain regulation was essential to prevent the flood insurance from becoming an additional encouragement to occupancy of flood plains. ${ }^{19}$

A study made in 1958 indicates that government regulation of land use for the purpose of controlling floods has increased in recent years. $^{20}$ From 1950 to 1958 , the number of communities having laws dealing with the subject rose from less than five to more than fifty. Among the stimulants to flood-plain zoning has been the activity of the Tennessee Valley Authority in lending technical asistance without cost to small communities on tributary streams and to other areas not adequately protected by TVA's extensive engineering works in order to help them draft and adopt land use regulations. ${ }^{21}$

Although the original term used in the literature has been "floodplain zoning" it is obvious that the essential consideration is regulation of individual decisions concerning land use, and it is immaterial whether the government chooses to call the regulatory law a channel encroachment law, zoning, subdivision regulation, health and sanitation code or building code. Any one locality may have all of these types of laws dealing with a flood plain. The over-all objective is similar for each of them. Throughout this paper "flood-plain zoning" will be used to cover each of the types of regulation which can be used to regulate land use for the purpose of affecting flood losses.

18. 70 Stat. 1082 (1956), 42 U.S.C. $\$ 2411$ (Supp. V, 1958).

19. See note 2 supra. It should be noted that flood insurance can become an additional encouragement to occupancy of flood plains only if the rate charged for the insurance is not accurately calculated to reflect risk. If there is a differential between fire insurance rates for brick and wood buildings, it cannot be said that fire insurance "encourages" the construction of wooden buildings.

20. Murphy, Regutating Flood Plain Developacent (University of Chicago Dep't of Geography Research Paper No. 56, 1958) (hereinafter cited as MURPEY).

21. For a description of this program see Address by Brig. Gen. Herbert D. Vogel, Chairman of the Board of TVA, National Conference on Flood Plain Regulation and Insurance, Chicago, IIl., Dec. 1, 1958 (Mimeo Press Release, TVA). See also SIIER, Flood Problems; MURPHy 71, 149-55. For an example of this activity see Fioods on REedY CREER IN VicinItY of Kingsport, TENNESSEE (1955), Supplement No. 1-Flood of April 16, 1956, Supplement No. 2-Revisions in Report (1957) (TVA, Division of Water Control Planning); Proposed Revisions to Zoning Ordinance and Subdivision Regulations for Adjusting to Flood Conditions at Kingsport, Tenn., Tenn. State Planning Comm'n, 1956; Kingsport Flood Zone Ordinance, passed July 22, 1957 (all referred to in MURPHY 198). 


\section{A Conceptual Framework for Analysis of Flood-Plain Regulation}

For purposes of analysis we need a conceptual framework within which to judge both man's reaction to floods and government policy concerning flood losses. ${ }^{22}$ The foundation of any such framework is the idea that flood losses are caused by man-a consequence of his decision to occupy a flood-prone area. Loss caused by occupancy of a flood plain can be eliminated by a decision to build protective works or by a decision not to occupy the flood plain at all.

In a market situation we can say that the possibility of flooding will affect the value of land in a flood plain. Values of land susceptible to flood should tend to be less than the values of other lands, by reason of flood interference with productive capabilities of the land, and by reason of the losses which floods cause to resources used in conjunction with land. For simplicity we can say that the value of land in a flood plain will tend to be reduced by the amount of damage likely to be caused by probable floods. If the probable damage for any conceivable use of flood-prone land exceeds or equals the productive value of the land, the value of the land will tend toward zero. This is because rational users would generally decide not to use or occupy this particular land.

A hypothetical situation, to which we will refer frequently, will illustrate this market analysis. Assume three parcels of land identical for all purposes except the possibility of damage from flooding. Parcel $A$ is completely out of flood danger and has a market value of $10 x$. Parcels $B$ and $C$ are susceptible to flooding, but with different frequencies. For parcel $B$ we will assume that the flooding is such that some productivity is possible and that the loss to be suffered from flooding, properly discounted to present value, is $3 x$. For parcel $C$ we will assume that the flooding is such that for any conceivable productive use of the land the resulting damage is $10 x$ or more. Thus we have parcel $A$ with a value of $10 x$, parcel $B$ with a value of $10 x$ minus $3 x$, or $7 x$, and parcel $C$ with a value of $10 x$ minus $10 x$, or zero. Parcels $A$ and $B$ will tend to be used commercially but parcel $C$ will be unused. In terms of willingness to take risk or to pay for risk elimination we can say that the owner of parcel $A$ will take all flood risk and will pay nothing voluntarily for protective works to protect his land from flooding. The owner of parcel $B$ will tend to use his land for a use

22. For other analysis for protection works see ECKSTEIN 19-46; WHITE, HUMAN Adjustarent 128-30; Renshoze 42-53; Hibdon, Flood Control Benefits and the Tennessee Valley Authority, 25 SOcIAL Econ. J. 48 (1958); White, The Limit of Economic Justification for Flood Protection, 12 J. LAND \& P.U. EcoN. 133 (1936). 
which produces only a $3 x$ loss, but might voluntarily choose to pay a sum approaching $3 x$ to someone who could sell him engineering work protection against flooding. The owner of parcel $C$ will tend not to use his land, but might be willing to pay up to $10 x$ for protective works for it. ${ }^{23}$

So far we have considered the factors which persons in the market for services of parcels $A, B$, and $C$ would take into consideration in deciding whether to buy or use these parcels. It is possible, however, that the decisions which persons make with respect to these parcels may influence the decision of users of other parcels. This is the phenomenon of external economies or diseconomies. Thus, a decision of the owner of parcel $C$ to build a flood protection work for his land might affect the flood risks of parcels $A$ and $B$ and of other parcels in the area. The decision might have the effect of protecting other land in addition to parcel $C$ and thus benefit the owners of the other land. Unlike most situations in the market economy there is no mechanism whereby the owner of $C$ can withhold this benefit until he is paid for it. Yet in terms of national welfare the decision of $C$ to build, increases welfare not only by the increase attributable to his land but also by the value of benefit conferred on other owners. The $10 x$ which the owner of $C$ might spend for his land might thus increase welfare by much more than the $10 x$ expenditure.

But the decision of the owner of parcel $C$ to build a flood protective work for his land might adversely affect other land owners. Thus he might decide to build an embankment along the upper edges of his land causing flood waters to back up onto adjoining parcels. Although welfare is increased by the $10 x$ expenditure which improves parcel $C$, it is also decreased by the reduction of value of other parcels, and there might be a net loss to welfare. Two other types of external cost in the flood situation loom large in the literature. A decision by the owner of $C$ to be foolish and to occupy his land without flood protection works seems to impose pain and suffering on people who, although outside the watershed, hate to see life or property endangered or lost. Also, if government has a policy of saving the owner of $C$ harmless from flood damage, then the decision to occupy $C$ imposes a cost on the taxpayers.

Let us now return to the original market analysis and introduce one or more government policies in order to determine their impact upon decisions of the owners of parcels $A, B$ and $C$ and, through those

23. Complexities such as the difficulty of estimating in advance flood probability and losses, or the difficulty of correctly estimating the chance of government building of protective works or reimbursing for loss, do not change the principles involved in this analysis; they merely make rational choice by private persons or by government more susceptible to error. 
decisions, on the economy or welfare. For present purposes we will ignore the external diseconomies which the decisions might create.

Government might decide to reimburse all owners of land in a flood plain for all monetary flood losses, or it might decide to assume all of the cost of construction of protective works. Analytically, the consequences of either of these policies is essentially the same-elimination of individual flood losses-and we will treat them as one policy: that of saving the individual from flood losses. Such a governmental policy would not affect voluntary decisions concerning parcel $A$ (the parcel out of flood danger), but would tend to increase the market values of parcels $B$ and $C$ toward the $10 x$ value of parcel $A$-in effect subsidizing the $B$ and $C$ owners to the extent that their possible flood losses are reduced.

Another policy choice available to government is to prohibit or limit the occupancy of a flood plain: that is, flood-plain zoning. If such a land use regulation were applied to parcel $A$ we can see that the regulation would be harmful to general welfare by preventing the use of this parcel in its most efficient or economical way. We assume, therefore, that the regulation applies only to parcels $B$ and $C$. The regulation may prohibit uses of the affected land which the market would produce; or it may permit uses which the market would discourage. We must look at the consequence of this regulation from two points of view; first, where, prior to the regulation, government had no policy on floods, so that the original market analysis applied; and, second, where, prior to the regulation, government had a policy of saving individual landowners from flood loss.

Where there had been no previous government policy on floods a regulation which prohibited all use of parcels $B$ and $C$ would be a regulation which for parcel $C$ permitted the same uses which the market would produce, that is, none. For parcel $B$ the regulation would be one which prohibited a recognized market use and which reduced its value from $7 x$ to zero. Economically, the effect on general welfare would be nil for parcel $C,{ }^{24}$ but for parcel $B$ the effect on general welfare would be exactly the same harmful effect which would follow from a regulation of parcel $A$ : it would prohibit the $7 x$ use which the market has determined is the most efficient or economical use. If the regulation does not prohibit all uses of parcels $B$ and $C$, we must look at what remains permitted. A regulation which permitted parcel $C$ to be used at all, or which permitted the $7 x$ use of parcel $B$, would have neither adverse nor beneficial economic consequence since the same uses which

24. The regulation would, of course, prohibit people from acting irrationally as to parcel $C$, which might constitute an economic gain. But we have no mechanism of evaluating the loss to welfare from restriction on the liberty of the owner of $C$. 
the market determined would result. But, if the regulation prohibited the $7 x$ use of parcel $B$, while permitting other, less productive, uses, the effect on general welfare would be, proportionately diminished, the same kind of adverse effect as would result from absolute prohibition.

Suppose, however, that the government has had a policy of saving landowners from flood losses and that it now proposes to adopt floodplain zoning. If there is to be a reversal of the previous policy of eliminating individual loss, the analysis which obtained in the case of no previous policy would be applicable. But if there is to be an ostensible continuance of the expenditures policy, an entirely different set of consequences ensues. If the regulation prohibits all uses of parcels $B$ and $C$, the government need no longer save the parcels and will gain $3 x$ and $10 x$; to this extent it will repeal indirectly the policy which has not formally been repealed. For parcel $B$, however, there will be an additional consequence of the prohibition: general welfare will be damaged $7 x$ by prohibiting productive use. If, however, the regulation permits a $7 x$ use of parcel $B$, there will be no effect on the subsidy policy - the government must continue to prepare to assume $3 x$ damage; and the same consequence will result from any permitted use of parcel $C$, although the absolute amount of the subsidy may be decreased.

Thus, assuming a formal continuance of the subsidy policy, adoption of a land use regulation policy would operate as repeal of the subsidy policy if it prohibited all use, but, unlike a direct repeal, it would decrease welfare to the extent that it prohibited any use which the market would permit. If the regulation permitted some use of the parcels, it might or might not result in a reduction of government expenditures, depending upon whether the uses it permitted were susceptible to losses lower than, or equivalent to, those determined by the market. But to the extent that it prohibited any use which the market would permit without subsidy, it would also effect a reduction in welfare. ${ }^{25}$

Government policy may be concerned with this analysis at three points. It may assume that individuals do tend to consider flood risk

25. The proponents of flood-plain zoning find an impact on government expenditure through operation of the "benefit-cost" formula. If everyone concerned properly evaluated the flood losses to be eliminated in an area zoned against damageable uses, it is possible that there would be insufficient benefit to warrant construction of levees or dams. This conclusion requires a threefold assumption however: (1) that the Corps of Engineers assesses damage reduced on the basis of restricted land values rather than unrestricted land values; (2) that there will be no successful political pressures to induce construction of the engineering work when probable benefit is less than cost; and (3) that political factors will not induce local governments to release land from restrictions if there is a protective work in the offing.

There is another possible policy for government. Government could buy by condernnation or negotiated purchase all damagable land in a flood plain and either leave it vacant or resell it with appropriate restrictions on use. See HoYT \& LANGBEIN 98. Under such a policy, government would have to pay "market value" for 
with the effect that parcels such as parcel $C$ are withdrawn from productivity, and may conclude that welfare is better served by inducing use of parcel $C$ in more productive ways through preventing flood loss or relieving owners of the consequence of floods. It may assume that individuals do tend to consider flood risks, but may decide that individual choice should be limited nevertheless because of the adverse consequences of their choice upon others. Or, third, government policy may be directed at the very assumption that people do consider flood risks, and may conclude that, since people do not or are not likely to act rationally with respect to floods, they must be protected from the consequences of their own acts. "Restriction" on free choice, or "compulsion," are such strong words in a free society that the burden is on him who proposes to limit freedom. As we will see, the burden is not sustained simply by saying that we must protect health and property. But the literature on flood zoning does tend to meet this burden of persuasion by developing one or more reasons why the opportunity of choice as to use of land in a flood plain should be denied.

\section{Reasons for Regulation of Land Use in a Flood-Plain}

The analysis which follows will show that in general the reasons advanced correspond to the points where it was suggested that government policy may operate within the foregoing conceptual framework. There is, however, in connection with this movement as much loose talk about the objectives of flood-plain regulation as there is about most proposals for exercise of government power. Thus, some of the proponents of public regulation of private property in flood plains would like to enlist all of the justifications for government itself on behalf on this type of regulation. This is the attempt to use the phrase which we say or write quickly as if it were one word: "to promote health, safety, protect property and promote the general welfare." 26

parcels $B$ and $C$, and this price would be either $7 x$ and zero, or $10 x$, if the market took into consideration, as it should, the possibility of government subsidy. See Iriarte v. United States, 157 F.2d 105 (1st Cir. 1946). Perhaps condemnation law would permit the government to exclude from market value that part of value attributable to the possibility of government subsidy. See United States v. Twin City Power Co., 350 U.S. 222 (1956).

This policy of purchase and the policy of flood-plain regulation were unsuccessfully urged as alternatives to dams and reservoirs after the disastrous Kansas City flood in 1951. See Kollmorgen, And Deliver Us from Big Dams, 30 LAND ECoN. 333 (1954); Kollmorgen, Settlement Control Beats Flood Control, 29 EcoN. GEograpHy 208 (1953); and see Report to the Kansas Industrial Commission discussed in 2 TASK Force RePort 814. See also examples given in House Coms. ON PUBLIC WORKs, op. cit. silpra note 14 , at $45-47$.

26. See Hoyt \& LANGBETN 97: "The basic requirement. . . is that [zoning restrictions] must serve to promote the health and safety of the community"; or, on same page: "The police power has traditionally been exercised to promote health and safety and to further general welfare by protecting property from damage." 
Without more, this phrase is a convenient substitute for thinking and analysis. There are many things which "promote the general welfare" which cannot be done at the expense of one or more individuals, and which must be done at the expense of all citizens by use of the taxing power. Undoubtedly a case could be made that it would promote general welfare to restrict by zoning the use of a particular parcel of privately owned land to "military airport uses only," or "to government office building uses only," or "to park uses only." Yet most of us would agree that such a regulation would not only be unconscionable but unconstitutional, ${ }^{27}$ and that, if government office buildings, airports and parks promote the general welfare, the public must purchase the desired addition to welfare. Likewise, there are many things which might promote health and protect property which we must obtain without compulsion because of principles about the freedom to choose carrying with it responsibility for consequences. We must analyze the reasons for flood-plain zoning into something more specific than general welfare or protection of life and property.

According to the literature, government should interfere with private decisions as to use of land in a flood plain, because:

(1) Individual choices result in unwise land use patterns in a flood plain; ${ }^{28}$

(2) Individual choices result in land uses which obstruct a flood flow so as to damage other land users in the use of their own land; ${ }^{20}$

27. For further development of this position see Freund, The Police Power $\$ 511$ (1904); Dunham, $A$ Legal and Economic Basis for City Planning, 58 Coluas. L. REv. 650, 663-67 (1958).

28. Cf. Address by Harold V. Miller, Executive Director, Tenn. State Planning Comm'n, Conference on Flood Plain Regulation and Insurance, Dec. 1-2, 1958 (Mimeo, Council of State Governments): "Really, it's amazing how slow we are to learn and how ready we are to take long chances. Let me give you an example. Late in $1955 \mathrm{I}$ was addressing a distinguished group in Philadelphia. I departed from my principal theme and prepared text to make what seemed to me an almost unnecessary reference to a situation in that section of the country. I said, somewhat apologetically, that it was my information that shortly after flood waters had receded along a particular stream in Pennsylvania, following the disastrous floods of the summer of 1955, that ground was broken for construction of a multi-million dollar plant on a site which was said to have been ten feet under water less than thirty days before! A voice from the audience could be heard clearly correcting my story with the statement, 'Hell, it was 13 feet.' Now I ask your, what can we do with persons and corporations who wish to take chances like that?" (Emphasis added.)

See also Moore, op. cit. supra note 11, where it is assumed that it is the province of the city planner to determine the "most effective use of the flood plain," in order to limit "unwise development in flood-hazard areas." Id. at 29. It is further stated that the city planner should determine whether "economic and location factors greatly overbalance the risk of potential flood damage." Id. at 32 . See also HoYT \& LANGBEIN : "Indiscriminate development . . constitute[s] a policy of doubtful visdom." Id. at 92-93. (Emphasis added.) "Home building. . is an example of the most unzerise use of flood land." Id. at 100. (Emphasis added.) See also id. at 107, 324.

29. See, e.g., The Iowa Channel Encroachment Law of 1949 which provides: "It shall be unlawful to suffer or permit any structure [or] ... obstruction ... to 
(3) There is not really rational choice, and therefore the individual land user must be protected against being "victimized" to the damage of his health, safety or property; ${ }^{30}$

(4) Individual choices result in land uses which require expensive public works such as reservoirs and levees or require costly disaster relief when the floods come, so that restriction on choice will promote welfare by reducing public expenditures. ${ }^{31}$

The first of these four reasons may be dismissed from our consideration summarily. Not since the demise of the sumptuary laws in the 18th century has "unwiseness" alone been a sufficient reason to invoke government restriction on individual choice. ${ }^{32}$ It may be unwise for an individual to buy a new model car every year or to buy a large American car instead of a smaller one, and it may promote welfare to have smaller cars, but few would recommend that we compel an individual to choose that which the majority of us might think wiser, or even that which might improve the property or capital of the car buyer. If the consequences of choice fall on the chooser and if he has full opportunity to consider these consequences, it is not a sufficient reason for limiting opportunity of choice to establish that the chooser

be erected . . . in or on any floodway, which will adversely affect the efficiency of or unduly restrict the capacity of the floodway. . . ." IOWA CODE ANN. \$455A.33 (Supp. 1958). (Emphasis added.) See also Murphy 16: "Anyone who builds in a potential flood area should expect to contend with the natural or regulated flood flow but should not expect to suffer losses through increased flows and flood heights caused by the acts or omissions of others." See also Hoyt \& LANGBEIN 99.

30. Cf. Fed. Reserve Bank of Boston, Planining for Floods in New England, New England Bus. Rev., Feb. 1956, p. 6: "Most of the unwise developments occur because builders are not aware or are unconcerned about the fact that a flood danger exists. ... Most individual property owners or builders are not capable or willing to assess the flood risks in each area. ..." SIIER, FLOOD Problenss 14, comments on a lack of knowledge making regulation necessary. See HOYT \& LANGBEIN 95, asserting that safe conditions of flood-plain use cannot be left to individual actions because far too many buy land or build on land subject to flood "unknowingly." "[U]nsuspecting," "ill-advised," and "unconscious" are other characterizations used by Hoyt and Langbein. Cf. WHITE, HUMAN ADJUSTMENT 51-53 ("frailties of memory," "unscrupulous subdividers"). The word "victimized" comes into the literature from the dissent in American Land Co. v. City of Keene, 41 F.2d 484 (1st Cir. 1930) where a developer, "victimized" by a city, sought to upset flood-plain zoning on the ground of fraud. Constitutionality was not in issue in the case.

31. MURPHY 47: "Flood-plain zoning is a means of regulation of land subject to flooding . . . so that flood damage can be minimized. Secondary benefits obviously accrue through the consequent protection of the health and general welfare of the community, but the main purpose is to reduce flood damage." See DUPAGE Country, ILL., ZoNING ORDINANCE \$ 4L (1957): "These areas [flood-plain areas] are created to protect public health and to reduce the financial burdens imposed on the community, its governmental units and its individuals by frequent and periodic floods. . . " The same provision is found in Hammond, Ind., Zoning Ordinance, as amended, $195 \dot{5}$; Kokomo, Ind., Ordinance; and Cincinnati, Ohio, Proposed Ordinance. See MUrPHY 175-189, app. B, for summary of many zoning ordinances; see also HoYT \& LANGBETN 97: "Present policy leads to a vicious circle: the greater the flood plain development, the greater the benefits that can be shown for flood protection."

32. See Freund, Police Power $\$ 430$ (1904). 
has made or is likely to make unwise choices, even though such choices damage his property or his health.

The remaining three reasons, however, are reasons similar to those successfully advanced for other restrictions on freedom, and correspond, as analysis will show, to the three points where government may operate with respect to the conceptual framework described in the previous section.

\section{A. Free Choice as to Occupancy and Use of a Flood Plain Should Be Restricted by Government Because the Use by One Orener May Harm Other Ozeners}

This is the most ancient of reasons for exercise of the police power and is one completely acceptable to all schools of politics, including those who adopt as a political faith the economic theories of Adam Smith. If the activity of one economic unit influences the productivity and satisfactions of another, then the first unit may be creating or destroying benefits for consumers in ways that do not enter into profitmaximizing calculations. Because of this external diseconomy, prices may not be a true reflection of general welfare, and a reduction of the diseconomy may increase welfare. ${ }^{33}$

The common-law doctrine of nuisance under the maxim sic utere tuo ut alienum non laedas has long dealt with external diseconomies or costs by giving the injured party, that is, the person on whom the uncompensated cost is imposed, a cause of action for damages against the producer of the harm. ${ }^{34}$

With respect to floods it is argued that human encroachment on the channels of a stream, including its flood channel, may increase the flood flow and height at other places on the stream and may, therefore, cause flood damage to others. It is proposed, consequently, that the government establish channel lines on a stream and prohibit or regulate any building, embankment or other obstruction within these lines. Common-law nuisance dealt with the problem of flood channel encroachment on the same basis, and for almost 100 years there have been statutes, ${ }^{35}$ primarily aimed at railroads, treating the

33. For fuller development of this theory see Pigou, Economics of WeLfare 149-79 (1920); ECKSTEIN 31-32, 38-42.

34. See generally on the law of nuisance 5 Power, REAL Property $\$ \S 704-07$ (1956); Prosser, TORTS 389-426 (2d ed. 1955).

35. See, e.g., Ind. Ann. Stat. §55-601 (1951) ; Kan. Gen. Stat. Ann. \$ 66-501 (1949); Minn. Stax. Ann. \$219.37 (1947); Mo. Ann. Stat. $\$ 389.660$ (1952); Mont. Rev. Codes AnN. \$72-644 (1947); Neb. Rev. Stat. \$\$31-201-226, 74-613 (1952); OHIo Rev. Code ANN. \$\$ 4959.01, 4961.21 (Page 1953); Tex. Rev. CTV. Stat. §6328 (1948); Wis. Stat. AnN. §88.38 (1957). 
problem of channel encroachment. A standard text on water law published over 100 years ago states:

"The use of a watercourse . . . in such a manner as to inundate or overflow the lands of riparian proprietors and other land owners above, is directly contrary to the injunction of the law-sic utere tuo ut alienum non laedas, for which, by the English law an action will lie as for a private nuisance. . . . [A] riparian proprietor . . has no right to build anything which, in times of ordinary flood, will throw water on the grounds of another. . . ." 36

An American text of about fifty years ago develops this point in some detail:

"Every stream . . . must have not only its ordinary channel which carries the water in ordinary times, but it must have also its flood channel to accommodate the water when additional quantities find their way into the stream. The flood channel of a stream is as much a natural part of it as is the ordinary channel. . . With the flood channel no one is permitted to interfere to the injury of other riparian owners." 37

The author remarked that litigation based on this principle was so extensive that it was necessary to have a separate chapter on it, in the same way that the book needed a chapter on polution, water diversion, and the like. ${ }^{38}$

The common law imposed liability on the builder of an embankment which caused or increased flood damage to other land users, except where the damage was caused by an "extraordinary flood." 39 Under this rule, difficulty arose both in establishing the damage which was "caused" by the defendant's encroachment, and from the concept of "extraordinary flood," which excused liability except where negligence was found. The earlier statutes attempted to meet these problems by imposing punitive as well as compensatory damage on the obstructor and sometimes by permitting an appropriate body to correct the obstruction at the expense of the obstructor. ${ }^{40}$

36. Angel, Law of Water Courses $\$ \S 330-34$ (7th ed. 1877). See also WoolRYCH, THE LAW OF WATERS 148-226 (1830).

37. 3 FarnhaM, Water and Water Rights 2562 (1904). For current treatment see 6A AMERICAN LAw OF Property $\$ 28.60$ (1954); 5 Poweld, Reaz Property $\$ 729$ (1956); REstateMENT, TORTS $\$ 841$, comment $f$ (1930).

38. 3 FARNHAM, op. cit. supra note 37 , at 1765 . A survey of the digest system indicates 37 American cases in the period 1658-1896, but in each 10 year period thereafter until 1956 there were $19,27,35,23,6$ and 12 respectively. Illustrative of the more recent cases are: Poynter v. County of Otter Tail, 223 Minn. 121, 25 N.W.2d 708 (1947); Stolting v. Everett, 155 Neb. 292, 51 N.W.2d 603 (1952); Atchinson, T. \& S.F. Ry. v. Hadley, 168 Okla. 588, 35 P.2d 463 (1934); Portsmouth v. Weiss, $145 \mathrm{Va}$ 94, 133 S.E. 781 (1926); Sund v. Keating, 43 Wash. 2d 36, 259 P.2d 1113 (1953). See generally Annot., 5 A.L.R.2d 57 (1949).

39. See cases cited note 38 supra.

40. See statutes cited note 35 supra. 
The current literature lists seven states which have channel encroachment laws of a somewhat different type. ${ }^{41}$ Primarily, these statutes attempt to prevent the obstruction from being built, either by requiring a license or by authorizing an administrative agency to remove the obstructing structure. The principle of these newer statutes, of their older counterparts, and of the common law is the same: preventing one person from exercising his freedom so as to impose uncompensated cost on others. The only questions for judgment here are the validity of the claimed causal relationship between building and flood damage, and the method of accomplishing the end (should it be a preventive or liability imposing rule?). The legal principles are the same for any method. ${ }^{42}$

\section{B. Since a Landozener Is Unable or Unwilling To Make a Rational Choice, Government Must Protect Him From the Harmful} Consequences of His Decision

Most non-lawyers writing in the field of floods do not phrase this reason in this form. They seem to state without qualification that land use regulations should be imposed in order to protect life and property. ${ }^{43}$ The one legal memorandum on the legality of flood-plain zoning, on which these writers rely, recognizes, however, that protection of life and property is not enough to invoke the police power of government; Wertheimer points out that zoning cases support the constitutionality of regulations prohibiting practices which harm others but that "floodplain zoning would in many cases aim at protecting a man against the consequence to himself of his own acts." 44 Wertheimer was bothered by this and stated that he was unable to find any decisions which "expressly sanction regulations to prevent one from doing something which would injure no one but himself," and, while he concluded that flood-plain zoning could be sustained, he could not base his conclusion on the simple objective of protecting life and property. Rather, Wertheimer concluded that individual freedom could be curtailed here in order to protect man from being "victimized," that is, from situations in which a rational choice is not made, and in order to protect the

41. Conn. Rev. Gen. Stat. §25-3 (1958) ; Ind. AnN. Stat. §27-1117 (1948); Iowa Code ANN. §455A.33 (1958); MAss. ANn. LAws ch. 91, §23 (1954); N.J. Rev. Stat. \$ 58:1-26 (1955); PA. Stat. ANN. tit. 32, \$§681-91 (1949); Wast. Rev. CODE $\$ 86.16$ (1951).

42. See text accompanying notes 88-92 infra.

43. Siler, Frood Problems is typical.

44. Werthencer, Flood-Plain Zoning: Possibilities and Legality with Specal Reference to Los Angeies County, Calmornia. (Calif. State Planning Bd. 1942) (hereinafter cited as WerthetMer, Flood-Plain ZonING). 
community against financial burden. ${ }^{45}$ It is the former of the two bases with which we are concerned in this section.

Previous legislation designed to protect man against unhappy choices may be classified into three types: (1) Where rational choice is thought to be impossible because it is difficult for man to acquire adequate information on which to act rationally. The pure food and drug laws, poison labeling laws, and licensing statutes for doctors and pharmacists are examples of legislation based on this assumption. (2) Rational choice, while possible, is difficult because the situation lends itself to fraud and deception by unscrupulous sellers. Regulations of auction sales and sales of securities, and much of the subdivision regulations are illustrative of this type of protection against man's own folly. In most instances this type of legislation is aimed at sale rather than purchase or use. (3) Rational choice is not possible because inferiority in bargaining position "compels" some to choose even a known danger. Minimum wage laws and building codes applicable to "tenement houses" are perhaps illustrative of this type of law. None of the literature purports to find inferiority of bargaining in connection with flood-plain land use, but the other two categories are relevant to flood zoning analysis. Wertheimer thought these two categories sufficient to sustain the validity of the regulation.

That there is substantial damage against which legislation can be aimed goes without question. While the annual loss estimates vary, they amount in property damage to between $\$ 1.50$ and $\$ 3.00$ per person in the United States per year or to $\$ 4$ to $\$ 10$ per acre of land susceptible to flooding. ${ }^{46}$ Although loss of life from floods is insubstantial-less than one-half of one percent of those killed in automobile accidents ${ }^{47}$ the social cost of flooding upon those made homeless is incalculable.

A considerable amount of the flood literature denies that man does take flood risks into his calculation. ${ }^{48}$ Indeed, from the literature, we should conclude, that men who do not live in flood plains are sufficiently cognizant of flood risk to write about it, but that those who do live in flood-prone areas will invest money without thought of flood. There is considerable difficulty in determining the basis of these writers' assertions that man does not consider flood risk. Too often the author, who believes an area should not be occupied for any purpose, concludes that, if it is occupied, it must be because the occupants acted irrationally,

45. Id. at $30-31$.

46. Hoyt \& LANGBEIN $77-90$ place the estimates of average annual loss at between $\$ 200,000,000$ and $\$ 500,000,000$.

47. See White, Human Adjustment 62. Hoyt \& Langbein 128 place loss of life at 0.35 persons per $\$ 1,000,000$ property damage.

48. See Hoyt \& LANGBeIN 95. 
that is, did not consider the risk. ${ }^{49}$ Yet the facts may rather mean that the market's consideration of the risk only so far devalued the land that it remained worthwhile to assume the risk for some purposes. ${ }^{50}$ If we put to one side statements of occupants made immediately after they have suffered flood damage ${ }^{51}$ and conclusions drawn from the fact of occupancy itself, and consider the evidence of Hoyt and Langbein, White and others, there is quite substantial reason to believe that man does consider flood risk in making his calculation.

The "key" evidence in all of the literature is the evidence that construction of protective works, or probability of such construction, stimulates development of the protected flood plain. ${ }^{52}$ If the reported increase in activity is caused by consideration of protection, this can only mean that, before protection possibilities were considered by the market, flood possibilities were also considered. ${ }^{53}$ Indeed many of the supporters of expenditures for flood protection works include "enhancement" of value as an objective ${ }^{\widetilde{4}}$ and the Corps of Engineers in-

49. See note 28 supra for an illustration. See also Hoyt \& LANGBEIN 324.

50. At one point Hoyt and Langbein conclude that land in a flood plain is "cheap" because of the public subsidy in the form of protection! Id. at 101 .

51. See White, Urban Occupance 106 (Carnegie, Pa.) and 139 (East St. Louis, Ill.) for illustrations.

52. White, after a study of 17 areas, concluded that an "obvious stimulant" to growth in a flood plain "is the construction of protection works." Id. at 215 . The study cites Dallas as the outstanding example of invasion of a flood plain triggered by flood prevention works. And in Los Angeles, for example, after flood control works were undertaken, land prices have "spiraled" upward. Id. at 154. In Waterbury, Conn. flood-plain land is cheaper. Id. at 187. HoxT \& LANGBEIN, 97 state: "A lowering of the level of floods by reservoir storage or exclusion of flood water by dikes encourages further crowding against the river by those relying upon the flood protection works. An increased demand may thus be created for such properties. : " (Emphasis added.) See also LEOPOLD \& MADDOCK 18; TVA, Value of Flood Height Reductions from Tennessee Valley Authority Reservoirs to the Alluvial Valley of the Lower Mississippi River, H.R. Doc. No. 455, 76th Cong., 1st Sess. (1939).

53. While White reports instances of increase in land values after construction of protective works, and many instances of stimulated construction, his general conclusion is that there were "relatively few clear indications of differentials in land values between unprotected flood-plain land and comparable land above the reach of floods." WhITE, URBAN OCCUPANCE 223. This is, as he admits, "paradoxical" when considered in connection with his other conclusions about protection stimulating change in flood-plain use. This paradox would seem to suggest that he has not yet constructed an adequate system to get at the relevant valuations. One possibility is that the point of time before which the market does not consider the possibility of coming flood protection has not been found by the researchers. Since the government policy of building protection works is so well-known, it may be that since 1936 the market always anticipates the effects of protection works. The White study gives instances where this has occurred. Id. at 222 . In any event, it would seem that the observable phenomena of rapid growth after construction of protection works, and of owners of vacant land joining in political pressure to secure protection from floods, can only mean that the market does assess flood risk, to a great extent.

54. See discussion of this point in 2 TASR FoRCE REPORT 736. The report states that the legislative history of the Flood Control Act of 1936 indicates that enhancement of value was not an objective. See also Leopold \& Madpox 239-40. 
cludes it in the calculation of benefit from preventive works. ${ }^{55}$ The basic theory of special assessment districts for levee construction recognizes that benefit is conferred on the flood-prone land..$^{56}$

Evidence offered by the flood experts in addition to price behavior is also substantial. More expensive land uses such as luxury housing avoid flood plains; blighted development and cheap houses tend to be found in flood-prone areas. ${ }^{57}$ The vacancy rate appears larger in flood-prone areas, and the land is slower to be developed than other land. ${ }^{58}$

Finally, a facetious note may be added by pointing out that the flood experts comment upon and commend farmers' often leaving vacant the land subject to periodic flood, and that the anthropologists note that Indians, before the coming of the white man, took flood risk into consideration by building on mounds or stilts in flood-prone areas. ${ }^{50}$ Since so much of the American legislation concerning farmers and Indians is based on an assumption that these groups cannot take care of themselves, it would seem to be an a fortiori conclusion that if farmers and Indians consider flood risks, then twentieth century urban man must also tend to take floods into consideration.

Skepticism as to the validity of the assertion that those who occupy flood plains fail to consider flood risks is not controlling, however, as to the legality of flood-plain zoning. For purposes of constitutionality, little is required in order to permit a legislature to conclude that regula-

55. Federaz Inter-Agency River Basin Committee, Subcommittee on Benfits and Costs, Proposed Practices for Economic Analysis of River Basin Projects 42 (1950).

56. See Werthemier, Flood Plain Zoning 27 for note of these cases. See also note 84 infra.

57. Much of the information in references cited note 52 supra is relevant, particularly for Wabash and Streetor. See also WHITE, URBAN OCCUPANCE 170. Most of new houses in Wheeling, W. Va. have been built on higher land, id. at 198; the same appears to be true for Boulder, Colo., id. at $94-100$; residential structures declined on the Binghamton, N.Y. flood plain, id. at 91. HoyT \& LANGBEIN 101 have similar comments on luxury housing. See also WHIte, Urban OCCUPANCE, infra note 58 .

58. WhITE, URBAN Occupance points out that the rapid growth of Albuquerque, N.M. has occurred more on the heights than in the flood-prone area, id. at 56 . In 1956, $92 \%$ of building permits were for residences on heights, id. at 58 ; the major growth of Augusta, $\mathrm{Ga}$ has been behind flood protective works, id. at 81, 87; in Binghamton, N.Y. most additions to structures were in protected areas, id. at 92; in Chattanooga, Tenn. much of development since 1920 has been above a floodline, $i d$. at 113 ; in Streetor, Ill. most of flood plain remains vacant although the area is growing, id. at 175 ; the same is true of Wabash, Ind, $i d$. at 181 ; the vacant land in Wheeling, W. Va. is more in the flood plain than out, id. at 198. There is also other evidence of adjusting to floods. White refers to the practice of highway and railroad builders in using elevation and fill, id. at 130; similar practices are employed by subdividers, $i d$. at 131 ; levee lines reduce the value of obviously unprotected land, $i d$. at 142 ; speculators buy land about to be protected, $i d$. at 157 .

59. White refers to Indian practices in lower Mississippi. URBAN Occupance 6. 
tion is needed. ${ }^{60}$ A more important question for purposes of drafting and for purposes of constitutionality is that of determining whether protection of the health and property of victims of deception or ignorance is an adequate or real basis for doing what flood-plain planners desire to do. It has been suggested that protection of health can be only a secondary benefit accruing from a flood-plain ordinance whose main purpose is to reduce flood damage. A regulation requiring elevation of buildings and foundations above a specified flood height has been scorned as flood-plain regulation: it only protects health and does not reduce property damage. ${ }^{61}$

\section{Restricted Occupancy of a Flood Plain Will Promote Welfare by Reducing Expenditures for Flood Prevention and for Disaster Relief and by Reducing the Subsidy Necessary To Secure "Reasonable" Rates for Flood Insurance}

This is the most satisfying of the reasons advanced for flood-plain zoning, although, as we shall see later, it is the most difficult legally. This reason, on its face, seems to be another instance of an external cost or diseconomy produced by occupancy of a flood plain. But here, unlike the situation where channel encroachment is involved, the external harm is to the public taxpayer, not to a user of land. Is this a significant distinction?

The old writers on the police power probably would have denied that the principle of external cost or nuisance was applicable to this type of harm. The harm to the taxpayer was said not to be the "proximate consequence" of an act of the individual." What was apparently meant was that between the act of the doer and the expenditure by the taxpayer was an intervening independent decision by the legislature to bear this cost or spend this money. But some of

60. Cf. Berman v. Parker, 348 U.S. 26 (1954). "We deal, in other words, with what traditionally has been known as the police power .... Subject to specific constitutional limitations, when the legislature has spoken, the public interest has been declared in terms well nigh conclusive." Id. at 32 .

61. See MURPEY: "Flood-plain zoning is a means of regulation of land subject to flood . . . so that flood damage can be minimized. Secondary benefits obviously accrue through the consequent protection of the health and general welfare of the community, but the main purpose is to reduce flood damage." Id. at 42 . "The intent of the ordinance is to reduce hazard to health by preventing frequent and prolonged flooding of septic tanks, not to reduce flood damages. Therefore it cannot be considered flood-plain zoning." Id. at 65 .

62. See Timdman, Limirations of Police Power (1886): "It may be said that any form of drunkenness produces harm to others in that it is calculated to reduce the individual to pauperism, and throw upon the public the burden of supporting him and his family. But that is not the proximate consequence of the act, and no more makes the act of drunkenness a wrong against the public than would be habits of improvidence and extravagance." Id. at 116. 
the earlier writers, when they dealt with liquor laws and the like, concluded that, once it is taken for granted that cost to the taxpayer is inevitable, then there is a genuine external cost from the activity which imposes financial burden on government, and that, for this reason, the activity may be regulated..$^{63}$

Almost all of the literature in the field of floods assumes that a government policy of permitting each man to take his own consequences from flooding is a politically unavailable governmental policy. If man occupies a flood plain, it is said, government will be compelled to build him protective works or to reimburse him for his loss. This conclusion is frequently documented. ${ }^{84}$ Since the expenditures are made by the federal government and the suggested regulating is to be done by local governments, there would seem to be an even stronger argument not to regulate. The persons benefiting from federal expenditure pay only a small proportion of the total tax cost, so that it would seem to be in the interest of residents of flood plains and the governments into which they are organized to endorse flood project works rather than to pass ordinances restricting the use of their own land. ${ }^{65}$ The conceptual framework with which we started indicates that, in many instances, the land use restriction is in reality a repeal of the policy which the literature assumes cannot be repealed. Nevertheless, many of the laws now regulating flood-pain occupancy recite the reduction of public expenditures as a reason for the regulation.

\section{The Legal Basis for Regulation of Land Use In Fiood-Prone Areas}

There are two general questions involved: (1) has the state legislature "enabled" the unit of government proposing regulation to pass a flood zoning ordinance; and (2) assuming that there is statutory authority, is the regulation or restriction constitutional?

63. See Freund, PoLICE PoWer $\$ 431$ (1904).

64. See Hart, Crises, Community and Consent in Water Politics, 22 LAW \& CoNTEMP. PROB. 510 (1957).

65. A number of writers recognize this point by suggesting that federal expenditures for floods be conditioned on adequate local zoning. See, e.g., HOYT \& LANGBEIN 96.

66. See, e.g., Freemont, Calif., Zoning Ordinance, art. 17, § 8-21700, 1958, entitled Flood Plain District: "Purpose. To protect persons and property from the hazards of development in flood water inundation, and to protect the community from the costs which may be incurred when unsuitable development occurs in such areas." See also DuPage County, Ilz., Zoning Ordinance §4L (1957): "Flood Plain Area. These areas are created to protect the public health and to reduce the financial burdens imposed on the community, its governmental units and its individuals by frequent and periodic floods. . . " The same or similar language is found in Hammond, Ind, Zoning Ordinance; Kokomo, Ind, Ordinance; Cincinnati, Ohio, Proposed Ordinance; and Milwaukee County, Wis., Proposed Ordinance. See Murphy 175-89, app. B. 


\section{A. Zoning Enabling Legislation}

Almost all states have zoning enabling legislation; ${ }^{67}$ the first question is whether these enabling statutes are broad enough to encompass regulation of flood plains. The statutes usually do three things: (1) grant power to a municipality to impose specified restrictions; (2) indicate the purposes for which the restrictions may be imposed; and (3) prescribe certain procedures which must be followed in adopting the zoning ordinance. We are here concerned only with the first two factors in enabling legislation.

The Standard Zoning Act prepared by the Department of Commerce in 1926 is the forerunner of most modern enabling acts. ${ }^{68}$ It empowers municipalities to regulate

"the height, number of stories, and size of buildings and other structures, the percentage of lot that may be occupied, the size of yards, courts, and other open spaces, the density of population, and the location and use of buildings, structures, and land for trade, industry, residence, or other purposes." 69

A subsequent section authorizes districting of the community. ${ }^{70}$ While the above quoted section itself begins with only the general statement of purpose "of promoting health, safety, morals, or the general welfare of the community," a subsequent section states a more specific set of purposes:

"Such regulations shall be made in accordance with a comprehensive plan and designed to lessen congestion in the streets; to secure safety from fire, panic, and other dangers; to promote health and general welfare; to provide adequate light and air; to prevent the overcrowding of land; to avoid undue concentration of population; to facilitate the adequate provision of transportation, water, sewerage, schools, parks, and other public requirements. Such regulations shall be made with reasonable consideration, among other things, of the character of the district and its peculiar

67. See generally on zoning enabling legislation, 1 RATHKopf, THE LAW OF ZoNing and PlanNing 57-106 (1956). YoKeLY, ZoNINg LAW AND PRACTICE $\$ \S 25.47-$ .51 (3d ed. rev. 1957).

68. U.S. Dept. of Commerce, A Standard State Zoning Enabling Act (1926) (hereinafter cited as STANDARD ACT). For one version of this model see BASSETT, Wirlians, Betrman \& Whitten, Model laws For Planning Cities, Counties aNd States 31-38 (Harvard City Planning Studies VII, 1935).

69. STANDARD ACT \& 1. Many state enabling acts are in this form. See, e.g., Ala. Cone tit. 37, \$\$772-74 (1940); ARIz. Rev. Stat. ANN. \$9-461 (1956); CaL. Gov'T Code $\$ 65800$; Conn. Rev. Gen. Stat. \$ 8-2 (1958); Fla. Stat. AnN. \$176.02 (1943); Ga. Code AnN. §69-801 (1957); N.Y. VIllage LaW § 175; PA. Stat. Ann. tit. 53, $\S 14752$ (1957).

70. STANDARD ACT $\S 2$. 
suitability for particular uses, and with a view to conserving the value of buildings and encouraging the most appropriate use of land throughout such municipality." 71

Under enabling legislation substantially in this form, may restriction on land use for any of the purposes mentioned in the previous section be imposed? It is obvious that we are concerned in flood-plain zoning primarily with restrictions on "location and use of structures and land." 72 Regulation of percentage of lot coverage, the number of stories, the amount of open space and the density of population will be hard to justify as flood-plain zoning regulations. In terms of the specific purposes of the regulation, we are interested in securing "safety from dangers," and " in promoting health and general welfare." None of the other specific purposes seem to fit flood-plain zoning, except, perhaps, sewerage. There is an additional admonition to the municipality, however, that the regulation shall be made with "reasonable consideration" of the objective of "encouraging the most appropriate use of land." A restriction whose object is to prevent a use from obstructing flood flow, or one whose object is to secure safety, would seem to fall within these stated general objectives. But if the objective is not primarily safety or prevention of channel obstruction, but rather reduction of flood loss, ${ }^{73}$ how can we qualify under the enabling act and yet give reasonable consideration to appropriate land use? If the market, for example, would say that an appropriate use of parcel $B$, even considering flood loss, was a $7 x$ use, and if no obstruction of the channel or element of safety is involved, it would not be "conserving values" or encouraging "appropriate use" of land to prohibit the $7 x$ use simply to save some government the cost of flood loss. At this point we must fall back on "general welfare," and assert that the restriction is to prevent a public expenditure and thus to promote the general welfare. This is satisfactory if the courts read the enabling act as almost a general grant of police power over land use, rather than a very narrow grant. In short, the old-style enabling act can probably be stretched to include flood-plain zoning.

It would seem, on the other hand, that those states which have been worried about the adequacy of the enabling acts have done more

71. STANDARD ACT $\S 3$. See also the enabling acts referred to in note 69 supra although a few of the latter have added the word "flood" as indicated at text accompanying note 74 infra.

72. The ordinances set forth in MURPHy 175-89, app. B, are primarily use regulations. Some (e.g., those of Napa County, Calif., Los Angeles, Calif., and West Lafayette, Ind.) require permitted buildings to be above a specified elevation; a few refer to sewerage requirements, foundation anchorage and the like.

73. MuRPHY suggests this objective. See note 61 supra. 
harm than good by additional language which they have inserted. Thus, a number of states have added, among the specific purposes of regulation, the word "flood" so that the purpose is "to secure safety from fire, flood, panic and other dangers." 74 The Tennessee form, which adds an additional sentence to the power section rather than the purpose section, is no better. It reads "special districts or zones may be established in those areas deemed subject to seasonal or periodic flooding, and such regulations may be applied therein as will minimize danger to life and property, and as will secure to the citizens of Tennessee the eligibility for flood insurance..."75 In each case the effect of the specific reference to floods is to limit zoning to the purpose of protecting life and property, and to exclude as an objective the reduction of public financial losses, that is, of general welfare other than safety of life and property. A much better type of amendment would be one based on the purpose clause of some of the existing ordinances; to read, for example: "to protect the public health and to reduce the financial burdens imposed on the community, its governmental units and its individuals by frequent and periodic floods and the overflows of lands." 78 .

An additional difficulty is the ambiguity of the term "periodic flooding." It is almost as bad as the common-law term "extraordinary flood." Is a flood whose chance of recurrence is 1 in 25 or 1 in 150 a "periodic flood"? The word "extraordinary" induced an Illinois court to say that any flood which was not an annual flood was extraordinary; ${ }^{77}$ presumably one which does not come at regular intervals would, then, fail to be periodic. ${ }^{78}$ It would be much better for the statute to establish some criteria as to the type of flood the municipalities may consider-"highest flood of record," "highest flood in the last twenty-five years," or some other formula more specific than "periodic flood." 79

74. The word is found in the Connecticut, Georgia and New York statutes cited in note 69 supra.

75. Tenn. Code Ann. §13-701 (Supp. 1958).

76. DuPage County, Ill., Zoning Ordinance §4L (1957), quoted in Murpey 179. (Emphasis added.)

77. Illinois Cent. R.R. v. Bethel, 11 Ill. App. 17 (1882). Other Illinois cases reject this unusual concept of flood frequency. See Ohio \& M. Ry. v. Ramey, 139 III. 9, 28 N.E. 1087 (1891).

78. See Lasch v. Corns, 120 Ind. App. 31, 89 N.E.2d 553 (1950) ; Pooler's Case, 122 Me. 11, 118 Atl. 590 (1922) referring to "periodic" as regular and systematic and the opposite of casual or irregular. Cf. Heath v. Wallace, 138 U.S. 573 (1891).

79. Other forms of enabling acts should be noted. ArIz. Rev. Stat. Ann. $\$ 45-2335$ (1956) authorizes certain enumerated counties and other governments to "co-operate with the United States . . . for the construction . . . of a local flood control project" and provides that these governments may " 4 . establish and enforce flood-channel limits and regulations, if any, satisfactory to the secretary of the army." 
The enabling legislation authorizing a government to impose subdivision regulations also must be scrutinized to determine adequacy for the objective of controlling flood losses. One of the model acts, extensively copied, mandates the plan commission, in approving subdivision plats, to require "that the land shown on such plats shall be of such character that it can be used for building purposes without danger to health." so Some may require dedication of certain areas to public uses such as streets and parks. If the community wishes a dedication of a right of way of drainage or of flood channel, this authorization would not seem adequate to acquire the right of way, even though the commission might be able to prevent building on the land under its power to protect health and prevent harm to others. ${ }^{81}$

\section{B. Constitutionality of Flood-Plain Regulation}

During some twenty years of discussion of flood-plain zoning, only two legal memoranda on the constitutionality of flood-plain zoning have been published. ${ }^{82}$ Both of these dealt primarily with due process, mainly under the federal constitution. The discussion which follows will treat three constitutional problems: (a) substantive due process, (b) equal protection of the laws, and (c) confliot between state and federal laws under the supremacy clause of the United States Constitution.

Before proceeding with these problems several lines of cases which frequently appear in the literature should be dismissed as not pertinent to our inquiry. The key question here is "regulation" or "restriction" on individual freedom as to use of property. We are not, therefore, concerned with the question whether some government may spend money to "buy" prevention of floods or a land use pattern different from that produced by the market; nor are we concerned with the question of whether some government may compel an individual to sell it all or part of his property rights in a flood plain. A proposal that government acquire a "flood channel" and make a park out of it or leave it vacant is not flood-plain regulation. ${ }^{83}$ For this reason cases

WIs. STAT. ANN. $\$ 59.97$ (1957) authorizes counties and towns "for the purpose of promoting the public health, safety and the general welfare" to regulate "the areas in and along or in or along natural watercourses, channels, streams and creeks in which trades or industries, filling or dumping, erection of structures and the location of buildings may be prohibited or restricted."

80. See BASSETT, op. cit. supra note 68 , at 42.

81. For an example of an attempt to secure a flood channel right of way through subdivision regulation, see N.J. STAT. ANN. § 40:55-1.20 (Supp. 1958).

82. Sahm, Flood Plain Zoning (U.S. Dept. of Interior, Office of the Solicitor, 1952, unpublished report in Docket and Records Section, Dept of Interior); WERTHEIMER, FLOOD-PLAIN ZONING.

83. For a discussion of attempts to compel a public benefit by use of police power see Dunham, $A$ Legal and Economic Basis for City Planning, 58 CouUn. L. Rev. 650 (1958). 
which uphold expenditures by government for engineering works for flood control, or which uphold use of the condemnation power for acquisition of land for levees and dams, are not pertinent to our inquiry. These cases, which state that it is a "public purpose" for federal or state government to expend or condemn for flood control because flood control promotes the general welfare, ${ }^{84}$ do not speak to the question whether government can also produce the desired result without paying for it.

The other line of cases not pertinent to our inquiry are those cases which state that it is within the "police power" of the state to organize, or to permit a specified percentage of landowners to organize, conservancy, flood control or drainage districts, and then to compel all landowners in the area to pay part of the cost of the engineering works constructed by the district. ${ }^{85}$ These cases deal with the problem of uncompensated external economies or benefits rather than uncompensated costs. The facts of the situation are that the dissenting owners share in the benefits of levees and reservoirs constructed by others without paying for those benefits, because the others are not in a position to withhold their product (protection from floods) from the "buyers" in order to force them to pay a market price for the services of the seller. At one time it was thought that, to justify this compulsory payment, either through assessment according to benefit or by general tax district, these laws must be put under the police power, and that "promotion of the general welfare," as well as economic benefit to the dissenters, was required. ${ }^{86}$ But public interest is, as Freund points out, a specious argument here; laws involving compulsory payment for repairs of party walls and division fences have also been upheld. ${ }^{87}$ The basic point in these cases is the "unjustness" of permitting a person to receive a service or benefit without paying for it. They are analogous to laws concerning "unjust enrichment" and are not regulatory "police power" cases. That it is constitutional to compel a flood-plain owner to pay for a protection work from which he receives benefit does not mean that it is also constitutional to prevent

84. See, e.g., Oklahoma ex rel. Phillips v. Atkinson Co., 313 U.S. 508 (1941); United States v. Appalachian Elec. Power Co., 311 U.S. 377 (1940). Generally on these cases see 3 President's Water Resources Policy Comm's, Water Resources LAW 5, 18 (1950).

85. See, e.g., Hagar v. Reclamation District No. 108, 111 U.S. 701 (1884); People ex rel. Setters v. Lee, 72 Colo. 598, 213 Pac. 583 (1923); County of Miami v. City of Dayton, 92 Ohio St. 215, 110 N.E. 726 (1915). For an argument that these cases are relevant see WeRTHEIMER, FLOOD-PLAIN ZoNINg 27.

86. See Freund, Police Power $\$ \$ 440-42$ (1904) on compulsory improvements.

87. For cases of this type see discussion in 5 Powell, Real Property $\$ \$ 687-91$ (party walls) and $\$ \S 692-97$ (fences) (1956). 
him from using his land in order to eliminate the need for a prevention work.

\section{Substantive Due Process}

The important analogies here in both the state and federal cases are cases upholding restrictions on use of property in order to prevent the user from harming others, cases involving restraints on freedom in order to save government expenditures caused by the prohibited activity, and cases involving restriotions on liberty of private will in order to prevent a person from harming himself or his property by reason of his ignorant or otherwise irrational choice.

Wherever it is reasonable to conclude that a particular use of a flood plain or flood channel is likely to increase flood damage to other users of land, there would seem to be no due process objection to restricting or even prohibiting the opportunity to make the use causing the harm. The common law, as we have seen, applied the doctrine of nuisance to these situations, including channel encroachment, and the legislature may forbid practices likely to produce harm of a type for which the common law imposed liability. It is this principle which makes the usual zoning case precedent for the validity of this type of flood-plain regulation. ${ }^{88}$ Thus, the Missouri channel encroachment law, which imposed punitive and compensatory damages on railroads, was upheld in Chicago \& A. R.R. v. Tranbarger ${ }^{89}$ against a claim that the statute took a right of way for drainage for which compensation had to be paid. The Court answered that, "the present regulation is for the prevention of damage attributable to the railroad embankment itself, and amounts merely to an application of the maxim sic utere tuo ut alienum non laedas." ${ }^{90}$ That the law before the Court was one imposing liability for damages, while the laws involved in flood-plain zoning are of a preventive type, presents no room for distinction in principle. The only significant difference is that a law which imposes liability imposes a charge only on the activity which in fact causes external harm, whereas a preventive or regulatory type excludes or regulates all activity of a specified class, whether or not the particular proposed activity in fact causes harm. As the leading zoning case, Village of Euclid v. Ambler Realty $\mathrm{Co}^{0}{ }^{91}$ points out, for administrative facility and because of difficulty of proof in each in-

88. Village of Euclid v. Ambler Realty Co., 272 U.S. 365 (1926), the leading case on constitutionality of zoning, makes use of the nuisance analogy.

89. 238 U.S. 67 (1915). See also Petersen v. Northern Pac. Ry., 132 Minn. 265, 156 N.W. 121 (1916) upholding a Minnesota statute.

90. 238 U.S. at 77.

91. 272 U.S. 365 (1926). 
dividual case, a legislature may lump together activities which might and those which do in fact cause harm. Many cases uphold this principle. $^{92}$

A problem for the courts in the case of a regulatory law is to determine whether the prevention of uncompensated harm is in fact the objective of the legislation. An assertion by the legislature that such is its objective is not enough; the court must analyze the law and determine this for itself. ${ }^{93}$ The more the statute excludes from its operation activities which need regulation as much as those regulated, the less the court is able to conclude that prevention of harm to others is a real objective. The Connecticut channel encroachment statute of 1955 is in difficulty for this reason. The statute prohibits obstructions or encroachments on channels only when the obstruction is "on any waterway under consideration for stream clearance, channel improvement or any form of flood control or protection work." 94 This language makes it appear that the objective is not to prevent obstructions which cause harm to others, but rather to prevent encroachment on rights of way and other areas which the government will need later for a public-work type of flood control. If the purpose of the law is to save the government money on acquisition of needed rights of way, then the law is trying to compel one owner to confer a benefit on all taxpayers and is unconstitutional. ${ }^{95}$ In Vartelas $v$. Water Resources Comm'n of Connecticut, ${ }^{96}$ the trial court thought that this was the objective of the statute and that the statute was, therefore, invalid. To withstand constitutional objection, the statute must establish a causal connection between the landowner's activity and the need for a structurefree channel. The Iowa statute of 1949 is free of this type of defect. It provides that "it shall be unlawful to suffer . . . any structure . . . to be erected . . . in or on any flood way, which will ad-

92. See, e.g., Miller v. Schoene, 276 U.S. 272 (1928), upholding a Virginia statute prohibiting red cedar trees within a certain radius of an apple orchard because of cedar rust disease communicated to apple orchards; Hadacheck v. Sebastian, 239 U.S. 394 (1915), prohibiting a brick kiln within the city limits because of the uncompensated harm from dust and smoke.

93. See, e.g., Town of Caledonia v. Racine Iimestone Co., 266 Wis. 475, 63 N.W.2d 697 (1954) where a quarry was prohibited in an agricultural district for ostensibly the same reasons as those given in the Hadacheck case. Since those reasons were equally applicable to other districts where a quarry was permitted, the law was held unconstitutional as an attempt to obtain an uncompensated public benefit (preservation of farm land), and as a denial of equal protection.

94. Conn. Rev. Gen. Stat. §25-3 (1958).

95. See note 84 supra. But cf. Headley v. City of Rochester, 272 N.Y. 197, 5 N.E.2d 198 (1936).

96. Unpublished opinion of Dube, J., Court of Common Pleas, Judicial District of Waterbury, Conn., Docket No. 16,018, decided July 18, 1958. The case is said to be on appeal to the Supreme Court of Connecticut. 
versely affect the efficiency of or unduly restrict the capacity of the flood-way. . . ." 87

A part of the Indiana Flood Control Act of 1945 has another type of weakness working against the finding of a constitutionally valid objective. $^{98}$ It prohibits the erection of any residential structure on a flood way, rather than any structure which obstructs. While the residential limitation may be valid as a health and safety measure for protection of occupants of the houses, it cannot easily be claimed that a residential structure will cause more harm to the channel than other types of structures. This may be a matter of equal protection as well as a matter going to the real purpose of the law. A number of the existing statutes restrict only the elevation of the foundations of certain kinds of structures in a flood way. ${ }^{99}$ These, too, would appear to be measures designed to protect the health of occupants rather than statutes designed to prohibit uncompensated costs. It might be said that the external cost is that the public "hates" to see people hurt and to see property damaged. No regulatory statute based on this psychological external cost has been found. ${ }^{100}$

Some or all of the regulations may have as their objective the reduction of the external cost of large public expenditures for works or relief. Is this a permissible end of restrictive legislation? On the basis of the few cases litigated in which the statutory objective was to reduce public expenditure caused by the regulated or prohibited activity, we may conclude that this is a permissible but seldom used objective of the police power. The most extreme type of statute which has been upheld with this objective is the statute providing for compulsory sterilization of those suffering from hereditary mental defects. In Buck v. Bell, ${ }^{101} \mathrm{Mr}$. Justice Holmes upheld this restriction of individual freedom on the ground that the regulation or compulsion saved the state the expense of taking care of the next generation of incompetents. Liquor laws, gambling laws, prohibition or control of prostitution, and laws regulating improvidence and improvidents, are other examples of laws frequently justified on the ground that they prevent or regulate activity which by reason of the tendency toward improvidence "com-

97. Iowa Code ANr. \$455A.33 (Supp. 1958). (Emphasis added.)

98. Ind. AnN. Stat. \$27-1117 (1948).

99. See MurPHy $175-89$, app. B.

100. It has been suggested that traffic laws prohibiting the game of "chicken" by adults even where there is no danger to third parties must be explained on this ground. See Valavanis, Traffic Safety from an Economists Point of Viez, 57 Q.J. ECON. 477, 478 (1958). Consider Wrs. STAt. ANN. \$346.62 (1958) making it a crime for a person driving a car "to endanger safety of his own person or property . . . by a high degree of negligence."

101. 274 U.S. 200 (1927). 
pels" the state to expend public funds in the form of relief. ${ }^{102}$ Where the regulation involves control of individual choices concerning the use of objects of property, it is harder to find examples of regulatory legislation the objective of which is to promote welfare by saving public funds. In Village of Euclid, ${ }^{103} \mathrm{Mr}$. Justice Sutherland upheld the exclusion of all industrial and commercial uses from residential districts on the ground, among others, that "the construction and repair of streets may be rendered easier and less expensive by confining the greater part of the heavy traffic to the streets where the business is carried on." This case, and those upholding restrictions on the weight of trucks on public highways in order to make highway construction and repair less expensive, amply support a restriction in flood-plain zoning for the same purpose. ${ }^{104}$

It must be established, however, as the later cases in planning indicate, that the public expense caused by the regulated activity is something abnormal or unique as distinguished from the public expense attributable to permitted development or to usual community affairs. ${ }^{105}$ Can flood-plain zoning meet this test? All of the existing ordinances seem to permit agricultural uses and a number of other uses such as recreational and entertainment facilities. ${ }^{106}$ The essential difference between the permitted and prohibited uses seems to be the magnitude of the probable damage. Presumably, since the amount of damage is likely to be less, it will be less likely that a proposed flood control project can qualify under the "benefit-cost formula." 107 That the amount is less, however, does not seem a sufficient basis of distinction. The damage to the public purse apparently must be caused uniquely by the activity regulated. Since damage to agricultural uses is of the same kind as damage to buildings, it would seem-as was said in the leading case on city planning, Mansfield \& Swett, Inc. v. Town of West Orangethat

"it is not a sound argument that the subdivision will attract additional dwellers, and thereby increase . . the need for additional police supervision. These are mere incidents of municipal growth. The proposed development . . . will plainly not create abnormal traffic hazards inimical to the public welfare." 108

102. See Freund, Police Power, $\$$ 453-57 (1904).

103. 272 U.S. 365,391 (1926).

104. See generally Note, Pozver of States to Regulate Interstate Carriers as to Sizes and Weight, 39 MICH. L. REv. 631 (1941).

105. See Mansfield \& Swett, Inc. v. Town of West Orange, 120 N.J.L. 145, 198 At1. 225 (1938); Archbishop O'Hara's Appeal, 389 Pa. 35, 131 A.2d 587 (1957). See also Smith, Minicipal Economy and Land Use Restrictions, 20 LAW \& Contearp. ProB. 481 (1955) and cases cited therein.

106. MURPEY 175-189.

107. See text accompanying notes $12-15$ supra.

108. 120 N.J.L. 145, 161, 198 Atl. 225, 234 (Sup. Ct. 1938). 
Assuming that government continues the policy of protecting or relieving flood loss, it would seem that construction of buildings in a flood plain and the resulting increase in damage potential is a "mere incident of municipal growth" with no "abnormal" increase in costs.

One of the problems encountered by regulations whose objective is to save the public money is the difficulty of establishing the regulatory means as reasonable means in light of available alternatives. In the case of flood-plain zoning to reduce costs to the public, the alternative methods are simple and effective: either to make no expenditure, or to charge those for whom it is made. Thus, in the field of truck weight regulation, difficulty in enforcement of weight limits has lead to a system of higher taxes on those weights which accelerate depreciation of the highways; ${ }^{109}$ in the liquor field, prohibition has been generally abandoned for a system of higher taxes on the sellers; and, in the field of improvidence, regulations designed to compel people to work or to enter public institutions have given way to compulsory insurance or savings schemes.

The last objective of land use regulation in flood plains is that of protecting the health, safety and property of individuals whose decision, if allowed to stand, would hurt themselves or their property. Assuming that an analysis of the statute shows that this is its objective, ${ }^{110}$ the only constitutional question is what must be shown to sustain it in addition to harm to an individual resulting from his own choice. Since freedom of choice normally implies that the chooser must take the consequences of choices rationally made, it is almost impossible to find a statute protecting people from their own folly. Something more is usually claimed for the statute: a showing that the choosers were "unable" to choose rationally, or that the seller is likely to overreach the consumer. Flood-plain regulation which takes the form of subdivision regulations might well invoke such a justification; ${ }^{111}$ almost any regulation of residences probably would fall into this category. More questionable, however, would be the use of this theory to justify regulation of industrial establishments in a flood plain. Difficult as it is to claim that commercial land users are likely to be "victimized," it is even more difficult to assert that persons involved in permitted

109. See, e.g., State of New York, Joint Comm. on Motor Carrier Taxation, Reports, LeG. Doc. No. 44 (1956), No. 37 (1957). Cf. Conn. Rev. Gen. Stat. \$14-268 (1958) imposing liability for damage to bridges on trucks over a specified weight.

110. An analysis of a statute may undermine the apparent objective. Thus, an objective of reducing public expenditures aimed at compensating individual losses is in conflict with an objective of preventing the occurrence of individual losses; an ordinance which permits some kind of uses belies an objective of protecting people against imprudent acts.

111. For a subdivision law upheld on this theory see, In re Sidebotham, $12 \mathrm{Cal}$. $2 d$ 434, 85 P.2d 453, cert. denied, 307 U.S. 634 (1938). 
commercial uses, such as recreational facilities, are less likely to be victimized than those involved in prohibited uses, such as automobile dealership..$^{112}$

Since a land use ordinance frequently will combine all three of the above objectives, it should be noted that the due process clause of the Constitution does not compel a legislative choice. It would appear, therefore, that land use regulation of a flood plain, if carefully drafted, can withstand general attack under the due process clause. A greater difficulty is the equal protection clause.

\section{Equal Protection of the Laws}

The person whose freedom to use his land as he chooses has been limited by state or local law may claim that his inclusion in the regulatory scheme is an unfair or illegal classification. The essence of this claim is that those similarly situated must be similarly treated, and that, although properly included within the regulatory scheme as far as due process is concerned, a person may nevertheless be heard on equal protection if others in a like position are not regulated. Judicial supervision of equal protection requires of the legislature only that the basis of classification be reasonably related to the ends sought. ${ }^{113}$

Where the objective of the regulation is to prevent channel encroachment-an uncompensated external cost to other users-the regulated landowner may be able to claim that others equally responsible for such a burden are excepted from regulation. For example, some channel encroachment laws prohibit ereotion in a flood channel of structures which adversely affect the channel, but make exceptions for structures erected by a public utility or a public agency. ${ }^{114}$ This discrimination would seem similar to that declared illegal in Ronda Realty Corp. v. Lazeton ${ }^{115}$ where apartment buildings, but not other traffic generating activities, were required to provide off-street parking facilities. While regulatory laws may make discriminations based on "degrees of evil," or on the basis that the few hurt by the excepted activity must bear this cost because of gain to the public, such considerations seem not available when the distinction between structures is based on the person of the builder. ${ }^{116}$ The basic evil of a classification

112. See MURPHY 175-189.

113. Cf. Brandeis dissent in Quaker City Cab Co. v. Pennsylvania, 277 U.S. 389, 406 (1928).

114. See, e.g., West Lafayette, Ind., Zoning Ordinance, art. III-A, §7 (1956) quoted in Murphy 180.

115. 414 I11. 313, 111 N.E.2d 310 (1953).

116. Thus, most jurisdictions have held void zoning ordinances which permit public but prohibit private schools, even though it is asserted that the benefit of 
which excludes private activity but which permits obstructions by government and by public utilities is that landowners within the flood water area are forced to bear the external cost of the permitted activity while other persons, without cost, share in its advantages. This would seem to violate all principles of equity or ability to pay in providing for public benefits.

Where the objective of the regulation is to prevent or reduce government expenditures, there may also be claims of unjust discrimination. No discoverable basis for a classification permitting some industrial uses but excluding others seems capable of reasonable relation to the aim of saving the public money. ${ }^{117}$

Where the objective is to protect health and property, the basic question is whether the state may make some people safer than others similarly situated. To say that there is less need for protection for some uses than others will be legitimate if this is indeed a reasonable conclusion. An example of potential difficulty is the flood zoning restriction in Sacramento, California, which permits residences only on lots of more than three-fourths of an acre. ${ }^{118}$ If we think of the owner of a one-half acre lot and of the owner of a three-fourths acre lot, we cannot say that one needs protection from deception more than the other; nor can we say that it is more desirable to protect the health and property of one than the other. The most we can say is that, since a three-fourths acre lot produces less density, there will be fewer people hurt than if we permit one-half acre lots. But this would seem clearly to be an impossible basis of classification for equal protection under the police power.

\section{The Supremacy Clause}

Assume that a state or local law regulating land use in a flood plain survives attack under state and federal due process and equal protection clauses; until Congress has clearly spoken, it must meet additional attack on grounds that the local law conflicts with or is superseded by federal law. Thus it is clear that unless Congress provides otherwise, no state or local law regulating use of a flood plain is applicable to a federal activity or building. ${ }^{119}$

public schools exceeds the external cost of noise and traffic to the neighbors. Com pare City of Chicago v. Sachs, 1 Ill. 2d 342, 115 N.E.2d 762 (1953) ; City of Miami v. State ex rel. Lear, 128 Fla. 750, 175 So. 537 (1937); and Catholic Bishop v. Kingery, 371 III. 257, 20 N.E.2d 583 (1939), with State ex rel. Wis. Lutheran High School Conference v. Sinar, 267 Wis. 91,65 N.W.2d 43 (1954).

117. See, e.g., Cincinnati, Ohio, Proposed Zoning Ordinance (1958), establishing a flood-plain district generally prohibiting use, but permitting an industry which needs water, industrial waste disposal or transportation. Quoted in MURPHY 183.

118. Quoted in MURPHY 54.

119. See, e.g., Tim v. City of Long Branch, 135 N.J.L. 549, 53 A.2d 164 (Ct. Err. \& App. 1947). 
A more difficult question is whether state regulation of private decisions in a flood plain is as a whole superseded by federal policy. The federal statutes now evidence a policy of preventing flood loss by providing for the construction of protective works to aid those who occupy a flood plain, ${ }^{120}$ a policy of providing disaster relief and other reimbursement for occupants who suffer loss, ${ }^{121}$ and a policy of purchasing unprotected land where it is thought inadvisable to build a protective work. ${ }^{122}$ State flood-plain regulation would be in direct opposition to the last of the three federal policies and would interfere with the working of the protective works policy. According to the federal statute, a work is not to be undertaken unless its benefit to landowners in the protected area exceeds its costs. If the state or municipality now prevents occupancy and use of a flood plain, it prevents the benefits exceeding the cost. Stated another way, the federal act is designed to enhance the value of protected land, while state zoning laws would be designed to depress that value, or at least to prevent realization of any enhancement due to a federal expenditure. ${ }^{123}$ Some local laws recognize this possible conflict and make provision for it. ${ }^{124}$

If no such provision is made in the local or federal law, does the conflict of policy make local law void as superseded by federal law? Twenty-five years ago a negative answer could have been given with some certainty. Today no answer can be given with certainty, but there is a leaning toward an affirmative answer. A number of cases now hold that even though there is no direct conflict between state and federal statutes, a conflict in policy is sufficient to void state law. ${ }^{125}$ However, it is difficult to find a case truly analogous to the situation

120. See, e.g., Watershed Protection and Flood Prevention Act of 1954, 68 Stat. 666, 16 U.S.C. \$§ 1001-07 (Supp. V, 1958) ; California Debris Comm, 27 Stat. 507 (1893), 33 U.S.C. $\$ \$ 661-87$ (1952); Flood Control Act of 1936, 49 Stat. 1570, as amended, 33 U.S.C. $\$ \$ 701-09$ (1952), as amended, 33 U.S.C. \$\$ 701-1-09 (Supp. V, 1958).

121. 64 Stat. 1109 (1950), 42 U.S.C. $\$ \$ 1855-55 \mathrm{~g}$ (1952), as amended, 42 U.S.C. $\$ \$ 1855 \mathrm{~b}-55 \mathrm{~d}$ (Supp. V, 1958). See also 69 Stat. 186 (1955), 33 U.S.C. $\$ 701 \mathrm{n}$ (Supp. V, 1958).

122. The policy of payment if flood-prone land is not used is an ancient policy. See Weeks Forest Purchase Act, of 1911, ch. 186, 36 Stat. 962, as amended by ClarkMeNary Act of 1924, 43 Stat. 654 (1924), as amended, 16 U.S.C. \$\$ 513-19 (1952), as amended, 16 U.S.C. $\$ \$ 513-16$ (Supp. V, 1958). See also the Flood Control Act, 52 Stat. 1216 (1938), 33 U.S.C. \$ 701i (1952).

123. This conflict is pointed out in LEOPOLD \& MADDOCK 240: "If flood control programs are aimed at . . . disaster prevention it is inherently logical to restrict continuing encroachment on the flood plain ... . but if the objective is to further the use and development of flood plain lands, zoning restrictions are undesirable. . . ."

124. See note 79 supra. MURPHy cites Palm Springs, Calif. as having an ordinance of this type.

125. Public Util. Comm'n v. United States, 355 U.S. 534 (1958); Wissner v. Wissner, 338 U.S. 655 (1950) ; Rice v. Santa Fe Elevator Corp., 331 U.S. 218 (1947); Cloverleaf Butter Co. v. Patterson, 315 U.S. 148 (1942). Cf. City of Tacoma v. Taxpayers of Tacoma, 357 U.S. 320 (1958). 
at hand. It is the purpose behind a federal expenditure, rather than the actual construction, which might be in conflict with a state regulatory scheme. No small reason for the absence of cases is the fact that adherence to the States rights doctrine seldom induces a state to forego the chance of a federal expenditure.

The closest analogy to our present problem is Stuyvesant Tozen, Inc. v. Ligham, ${ }^{128}$ a 1955 New Jersey case which, unfortunately for our purposes, was not taken to the United States Supreme Court. In section 608 of the National Housing Act Congress expressed a policy of stimulating construction of apartment houses by exceedingly generous insured loans for such construction. The section also provided that the rents of the mortgagor were subject to control by the Federal Housing Administrator. Plaintiff had built an apartment house pursuant to this act, and his proposed rent schedule had been approved by the administrator. Thereupon, the New Jersey Rent Control Administrator (federal rent control having ceased) attempted to make the state rent control law applicable to the project and imposed a lower rent schedule. The Supreme Court of New Jersey assumed that if there was a conflict in policy the federal law controlled. But the majority concluded that the rent provisions in the federal act were designed to protect the government's investment and to obtain low rents for tenants. There was no conflict, therefore, as long as the rent was high enough to guarantee the United States a return on its investment. ${ }^{127}$ But if the majority had seen the federal policy as one of protecting its investment and securing profitable returns to the private investors whom it subsidized, then the implication of the majority opinion is that the state regulatory policy must fall. Similarly, in the flood zoning problem we have a federal policy of expending money to benefit the land in a flood plain. On the face of it, a state law designed to prevent this benefit from accruing would seem to be in conflict with this policy and, therefore, superseded by federal law. This would appear clearly true of a situation where, after a federal project had been commenced on certain assumptions concerning floods and flood damage, a state act was passed or applied to prevent this damage from occurring. A distinction might be drawn between that situation and one where the federal government had committed itself to nothing and there were on the books only the general statutes prescribing a method or procedure if Congress should authorize a specific project and appropriate money.

126. 17 N.J. 473, 111 A.2d 744 (1955), 10 Rutgers L. Rev. 441 (1956).

127. This view of the rent provisions seems unsound in light of the policy of getting housing built. 
The most persuasive argument against federal supersedure is that the federal act and its history indicate a desire to co-operate with the states and not to supersede them. ${ }^{128}$ Since many other acts with similar evidence of co-operative attitude have been held to supersede state law, prudence would seem to require an amendment to the federal acts making clear that no conflict or supersedure is intended.

\section{Conclustons}

1. Land use regulation to prevent flood losses is an indirect repeal of the federal policy of assuming the cost of flood losses.

2. Unlike an outright repeal of such a policy, land use regulation may decrease general welfare rather than promote it, if it prohibits uses of the flood plain which, upon a proper calculation of flood risk, the market would have made.

3. Land use regulation of flood plains can be justified on the basis of the external costs which uses of flood-prone areas create for other land users and the public, and can also be justified, although less easily, on the basis of the inability of individuals to assess flood risk accurately.

4. Land use regulation of flood plains with the objectives of preventing external diseconomies and protecting users from their own purportedly inevitable irrationality in the assumption of flood risk, presents an adequate basis to withstand attack under the due process clause of the Constitution. Some particular ordinances may fail because of failure of the draftsman to consider problems of equal protection of the laws.

5. Present confusion in the doctrine of federal supremacy makes it difficult to hazard a guess whether land use regulations by state and city may withstand a claim that federal flood control policy has occupied the field and superseded state policy.

128. 2 TASK FORCE REPORT 735-41, 743; Engelbert, Federalism and Water Resources Developinent, 22 LAW \& CoNTEMP. PROB. 325 (1957) and references, supra note 1 , cited for history of federal-state cooperation in flood control. 